Article

\title{
Soil Seedbank of Parthenium Weed (Parthenium hysterophorus L.)
}

\author{
S. M. R. Karim* , C. M. Maszura and M. Z. Norhafizah \\ Faculty of Agro-Based Industry, Universiti Malaysia Kelantan, Jeli Campus, 17600 Jeli, Malaysia \\ *Corresponding author: rezaul@umk.edu.my, Tel: +60169355041
}

\begin{abstract}
Weed seedbank is an indication of future weed infestation potential of the species and is essential for making strategic planning for its sustainable management. Parthenium weed (Parthenium hysterophorus L.) is an invasive alien species threatening the biodiversity and the environment in Malaysia. A study was, therefore, conducted to estimate the soil seedbank of the weed at four soil depths of four villages of Kuala Muda, Kedah. The aim was to indicate the critical $\mathrm{s}$ of parthenium weed seedbank in Malaysia. Soil samples were collected from the sites using a soil core. The seeds were extracted from the soil samples with sieve shaker at the Universiti Malaysia Kelantan laboratory, Jeli Campus. The study indicates that the weed seedbank is in critical level at the area. The highest number of weed seeds $\left(6915 / \mathrm{m}^{2}\right)$ was found in $\mathrm{Kg}$. Kongsi 6, followed by $\mathrm{Kg}$. Sungai Tok Rawang (4481 seeds $/ \mathrm{m}^{2}$ ). The top layer of soil, $0-5 \mathrm{~cm}$, contained the maximum number of weed seeds $\left(4878\right.$ seeds $\left./ \mathrm{m}^{2}\right)$ and a significant number of seeds $\left(316 \mathrm{seeds} / \mathrm{m}^{2}\right)$ were noticed at 10 $15 \mathrm{~cm}$ soil depth. The study suggests the Malaysian government to take immediate action to control parthenium weed seedbank of the sites.
\end{abstract}

Keywords: parthenium weed, soil seedbank, soil depth, seed extraction, sieve shaker

\section{Introduction}

Parthenium weed (Parthenium hysterophorus L., Family: Asteraceae) is a noxious weed, locally known as 'Rumpai Miang Mexico' is one of the Invasive Alien Species (IAS) unexpectedly introduced to Malaysia. It can disturb nature and agro-ecosystems by reducing the biodiversity of native flora, compete with certain crops, pollute the environment, and hazard to human and animals health (Parthasarathi et al., 2012; Devi et al., 2014; Karim et al., 2016; Karim et al., 2017a). It was detected invading Kedah, Malaysia as the largest area infesting in 2015 (Department of Agriculture (DOA), 2015). Among all districts in Kedah, Kuala Muda is the most severely infested area. Seed of parthenium weed ranges from 2- $2.5 \mathrm{~mm}$ in size (Patil 2013; Kaur et. al, 2014) and these can remain dormant until ten years in soil. A single plant of parthenium weed can produce a large number of seeds ranging from 25000 to 100,000 (Kaur et al., 2014). Parthenium weed spread too many countries because of its capability of producing a good number of seeds, and fast spreading capability (Worku, 2010). This phenomenon contributed to deposit a considerable level of soil seedbank in the infested areas. Previous studies conducted by Adesina et al. (2012) and Ayele et al. (2013) show that the increasing of soil depth decrease is the weed seed number. They stated that, soil seedbank of parthenium weed was higher at $0-3 \mathrm{~cm}$ of surface layer and it gradually decreased to $81.5 \%$ as soil depth increased to $6-9 \mathrm{~cm}$. In addition, Karim et al. (2017b) found that soil seed banks of parthenium weed remained up to $15 \mathrm{~cm}$ depth at Batang Kali, Selangor, Malaysia. Nguyen et al. (2010) reported that parthenium weed seed generally found up to $20 \mathrm{~cm}$ of soil depth. The seeds can remain dormant in soil for many years (Masum et al. 2013; Kaur et al., 2014). There are many factors e.g. cropping practices, influence of diffused light to surface layered seeds, etc. which trigger the weed seed germination from the seedbank. However, weed seed bank can be reduced through controlling the weed seedling after allowing it to germinate; reducing the number of weeds that can produce the seed, and applying effective pre-emergence herbicide or soil-applied mycoherbicide in soil. According to Karim et al. (2017b), ruining weed seeds in seedbank is one of crucial strategies in weed 
management. The previous and future plant populations within a habitat can be predicted through the data of weed seedbank records (Golafshan \& Yasari, 2012; Karim et al. 2017b). Thus, the recognition of weed seedbank is important since it can act as a guideline for weed management in Malaysia. The objective of this study was to determine the weed seed density in four soil depths of four locations in Kuala Muda, Kedah, Malaysia.

\section{Materials and Methods}

\subsection{Collection of Soil Samples}

Soil samples were collected using soil core of $7.5 \mathrm{~cm}$ diameter from four soil depths $(0-5 \mathrm{~cm}, 5$ $10 \mathrm{~cm}, 10-15 \mathrm{~cm}$ and 15-20 cm) in four villages namely, $\mathrm{Kg}$. Sungai Tok Rawang, $\mathrm{Kg}$. Zainal Abidin, Kg. Kongsi 6 and Taman Cahaya Baiduri in Kuala Muda, Kedah, Malaysia (05 38.770' N, $100^{\circ} 28.771$ E) (Figure 1). The soil sample was collected from five spots of each location following the inverted 'M' pattern of Begum et al. (2006) and Ayele et al. (2013) (Figure 2). Within each sampling spot, five randomly selected sub-spots were marked for sample collection. Soil samples were collected from four soil depths in each sub-spot, and each core was separated with a differently marked plastic bag.

Malaysia

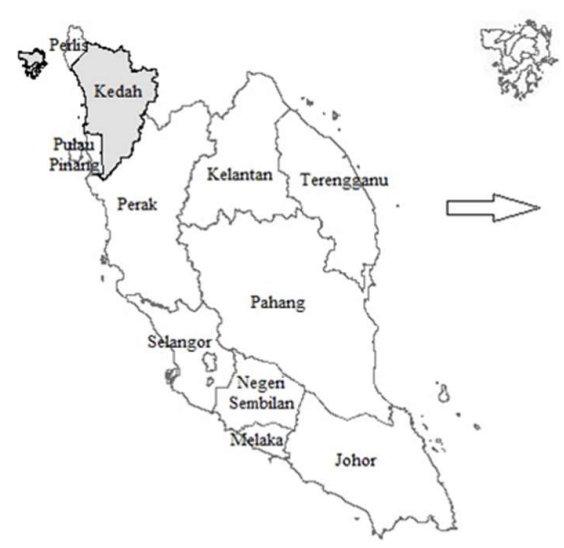

Kedah

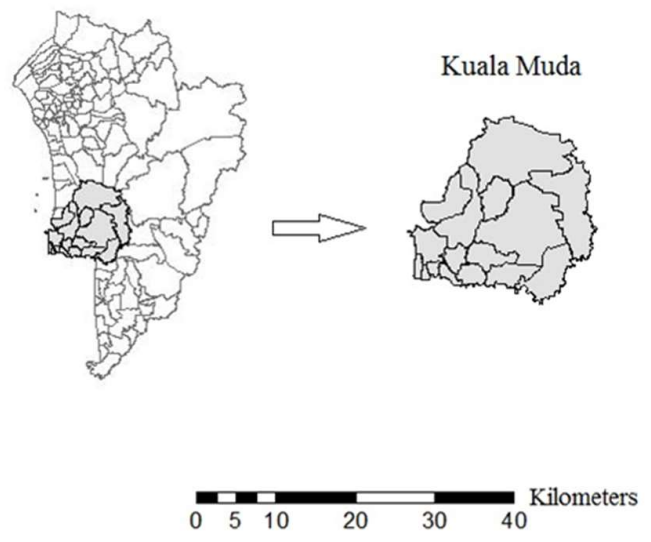

Figure 1. Peninsular Malaysia showing the location of the study 


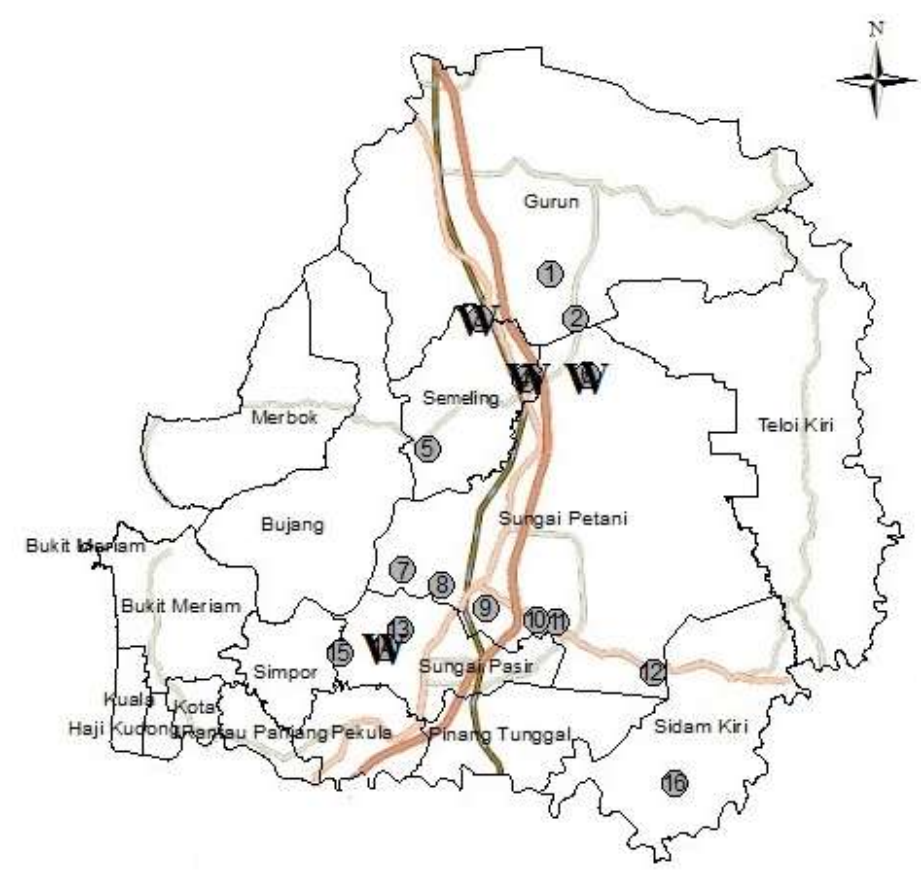

(B)

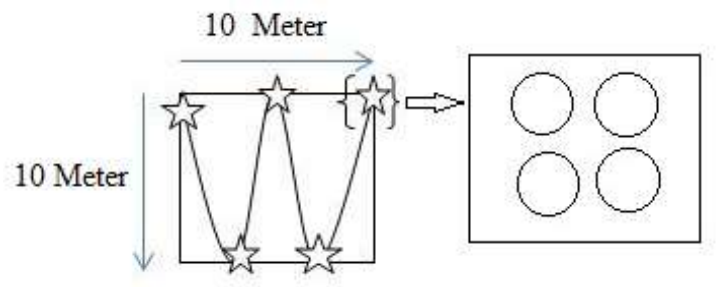

Figure 2. Sampling locations in Kuala Muda, Kedah (A) with inverted ' $M$ ' pattern at each spot (B).

\subsection{Seed Extraction from Soil Samples}

The collected soil samples were dried in an electric oven at 60 to $70{ }^{\circ} \mathrm{C}$ for one hour to improve dispersal of clay aggregates. The weed seed extraction was done using the direct seed extraction technique (Mesgaran et al. 2007). The sieve shaker with different sizes of mesh was used to remove all unwanted plant roots, debris and different sizes of other particles from the weed seeds settled at the bottom of the sieve. When the fine particles had passed through the sieves, the remainder of the sample-like sand particles, organic debris, clay soil and seeds that had not fully dispersed from the soil remained on the top sieve. The parthenium seeds were separated from other seeds. They were identified through observation by noting their small size, triangular shape and blackish appearance. The number of seeds on the sieves was counted and recorded. The number of seeds was estimated using the following formula:

Number of seeds $/ \mathrm{m}^{2}=($ Number of seeds $/$ core $) \times\left(10000 /\right.$ Area of core in $\left.\mathrm{cm}^{2}\right)$ 
The area of core $=\pi r^{2}$

Where $\pi$ is a constant and is equal to $3.14, r=d / 2$, where $d=$ diameter of the core $(7.5 \mathrm{~cm})$

\subsection{Data Collection and Statistical Analysis}

The experiment was laid out in randomized block design with four replications. The collected seeds were tested for viability in the laboratory using 9-cm diameter Petri dishes lined with two layers of filter papers, Whatman No.1 and moistened with $5 \mathrm{ml}$ of distilled water. The Petri dishes were kept in a seed germinator at $27^{\circ} \mathrm{C}$ for 7 days. Seeds are considered to have germinated when they attained a length of $1 \mathrm{~mm}$. The data collected then were tabulated for statistical analysis using the Statistical Package for the Social Sciences (SPSS) (Landau \& Everitt, 2004). Analysis of variance (ANOVA) of the data was done to discover the significant differences between the means. The Duncan New Multiple Test was used to indicate the significant difference between the treatment means.

\section{Results and Discussion}

\subsection{Weed Seed Bank in Different Locations}

The number of weed seeds (mean values) in the different locations of the sampling area of Kuala Muda, Kedah are presented in Figure 3. It was noticed that the size of the weed seedbank significantly differed between the different locations, except Location 1 (Kg. Sungai Pasir) and Location 3 (Kg. Sg. Tok Rawang ). Location 4 (Kg. Kongsi 6) recorded the highest number of weed seeds in the soil. On an average, there were 1.73 thousand seeds per $\mathrm{m}^{2}$ in the soil, followed by $\mathrm{Kg}$. Sg. Tok Rawang, with 1.12 thousand seeds per $\mathrm{m}^{2}$. However, the size of the weed seedbank was significantly smaller at the location 2 (Kg. Zainal Abidin) with 0.25 thousand seeds per $\mathrm{m}^{2}$. Based on Menalled (2008) report, the matured seeds from plant fell and stayed on soil surface as seedbank through various ways. The seed dispersal is usually influenced by wind flow, vehicles or human activities (Anon, 2003). The seeds are also easily dispersed via water, wind, vehicles, machinery and other vectors. The distance of seeds movement depends on the process of dispersal and the species of weed. According to Noroozi et al. (2012), the factors that influence the rate of dispersal might be the habitat, environmental conditions, weed species, seed characteristics, seed density and also the seed distribution pattern. Gomaa (2012) reported that distribution of soil seed bank might also be related to the soil condition like soil structure, soil chemistry, and size of soil particles.

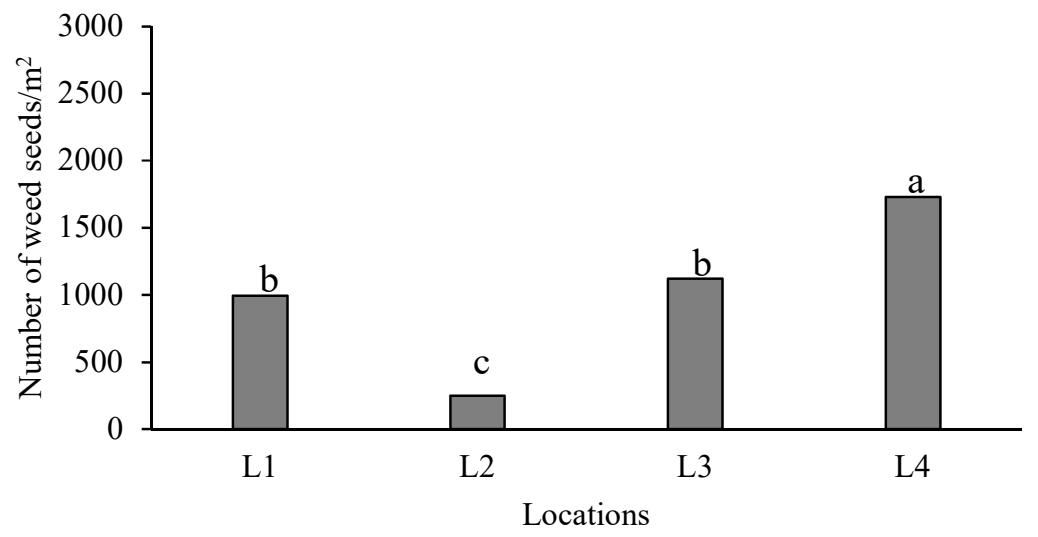

Figure 3. Number of parthenium weed seed in four different locations at Kuala Muda, Kedah

(Note: L1=Kg. Sungai Pasir, L2=Kg. Zainal Abidin, L3=Kg. Sg. Tok Rawang, L4=Kg. Kongsi 6. Dissimilar small letters on the bars indicate significant difference.) 


\subsection{Weed Seed Bank at Different Soil Depths}

The parthenium weed seed bank status at Kuala Muda, Kedah was investigated at different soil depths to get idea about the time of seed deposition in the soil (Figure 4). It was found that the number of seeds per unit area varied significantly within different soil depths, except at D3 (10-15cm) and D4 $(15-20 \mathrm{~cm})$. The highest number of parthenium seeds, 2.78 thousand seeds per $\mathrm{m}^{2}$, was noted in the shallower depth, 0-5 cm. This finding was in agreement with a study conducted by Buhler et al. (2009) who reported that around $60 \%$ of the total number of weed seeds was found at the top soil depth of 0-5 cm. The number of weed seeds decreased logarithmically with the soil depth. Price et al. (2010), Yang and Li (2013), and Karim et al. (2017b) investigated the density of soil seedbank and found higher number of seeds on top $5 \mathrm{~cm}$ of soil surface in dry and wet land area samples. They also reported that, soil seedbank declined monotonically with depth decreasing.

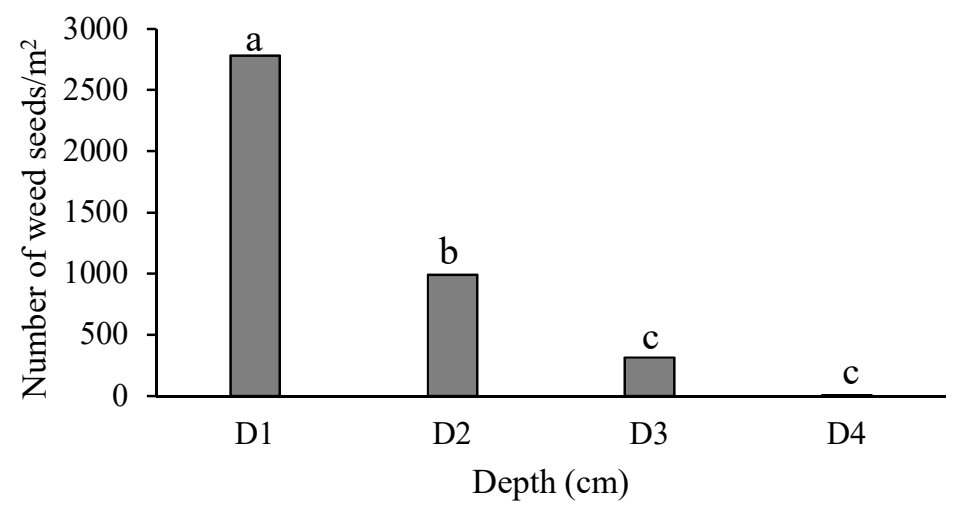

Figure 4. Mean number of parthenium weed seed in four different soil depths $(\mathrm{cm})$.

(Note: D1=0-5cm depth, D2=5-10cm depth, D3=10-15cm depth, D4=15-20 cm depth. Dissimilar small letters on the bars indicate significant difference.)

\subsection{Interaction between Location and Soil Depth}

Interaction effects indicate that the number of weed seeds varied in the different soil depths from the four different locations of Kuala Muda, Kedah (Tables 1 and 2). Based on Table 2, the number of weed seeds in the different depths of soil was significantly different in the four locations, except at 15-20 $\mathrm{cm}$ soil depth. The maximum number of weed seeds, 11136 seeds $/ \mathrm{m}^{2}$ was noticed at $\mathrm{Kg}$. Kongsi 6 site under the surface layer of 0-5 cm depth (Table 2). This might be due to different environmental conditions and human activities in the area. Navie et al. (1996) stated that the presence of 3200 to 5100 seeds/ $\mathrm{m}^{2}$ in Australia was considered a danger and that it posed a threat to the environment. According to Espinar et al. (2005) and Price et al. (2010), the viable seeds are commonly consisted on soil surface. However, in dry habitat with dry season, the seed density was increased at $12-16 \mathrm{~cm}$ of soil depth level. Thus, location and soil depth were important to determine the status of parthenium weed seedbank. Yang and Li (2013) found that soil seedbanks were similar at the top of $5 \mathrm{~cm}$ of soil surface at Mudflat, Marsh, Meadow, and Shrub. They also observed that soil seed bank significantly different in layer of 5 - $10 \mathrm{~cm}$ soil depth among those habitats. However, the vertical distribution of seeds in soil profile mainly depends on type of tillage for soil management practices (Menalled 2008). He found around $80-90 \%$ of seeds between $0-10 \mathrm{~cm}$ in the soil profile in reduced tillage field and the most of the seeds keep on the soil surface in no-till field. 
Table 1. Analysis of variance showing mean effects and interaction effects of location and depth of soils on number of weed seeds extracted

\begin{tabular}{lccc}
\hline \multicolumn{1}{c}{ Source } & $\mathrm{df}$ & $\mathrm{F}$ & Sig. \\
\hline Corrected Model & 15 & 15.37 & 0.00 \\
Intercept & 1 & 134.93 & 0.00 \\
Location & 3 & 11.89 & 0.00 \\
Depth $(\mathrm{cm})$ & 3 & 49.81 & 0.00 \\
Location * Depth & 9 & 5.05 & 0.00 \\
Error & 304 & & \\
Total & 320 & & \\
Corrected Total & 319 & & \\
\hline
\end{tabular}

$\mathrm{Df}=$ degree of freedom, $\mathrm{F}=$ statistical $\mathrm{F}$ value, Sig. $=$ Significant, ${ }^{*}=$ Interaction, $\mathrm{cm}=$ centimeter

Table 2. Interaction effects of soil depth and location on the number of parthenium weed seeds $\left(\mathrm{No} . / \mathrm{m}^{2}\right)$ in Kuala Muda, Kedah

\begin{tabular}{|c|c|c|c|c|c|c|}
\hline \multirow{2}{*}{$\begin{array}{l}\text { Soil Depth } \\
(\mathrm{cm})\end{array}$} & \multicolumn{6}{|c|}{ Locations (Number of weed seeds/ m²) } \\
\hline & 1 & 2 & 3 & 4 & Total & Mean \\
\hline $0-5$ & 2478 & 668 & 3112 & 4878 & 11136 & $2784^{a}$ \\
\hline $5-10$ & 1177 & 226 & 996 & 1562 & 3961 & $990.25^{b}$ \\
\hline $10-15$ & 316 & 102 & 373 & 464 & 1255 & $313.75^{c}$ \\
\hline $15-20$ & 11 & 0 & 0 & 11 & 22 & $5.5^{c}$ \\
\hline Total & 3982 & 996 & 4481 & 6915 & 16374 & 4093.5 \\
\hline Mean & $996^{\mathrm{b}}$ & $249^{c}$ & $1120^{\mathrm{b}}$ & $1729^{a}$ & & \\
\hline
\end{tabular}

Note: 1=Sungai Pasir, 2=Kg. Zainal Abidin, 3=Kg. Sg. Tok Rawang, 4=Kg. Kongsi 6, 0 -5=Depth 1, 5-10=Depth 2, 10

$-15=$ Depth 3, and $15-20=$ Depth 4; Dissimilar small letters on the bars indicate significant difference).

\section{Conclusions}

In conclusion, the distribution of parthenium weed seeds in the study area is at critical level and needs immediate action to combat the menace by integrated approach of physical, chemical and biological methods. Research need to be done to find out seed eating insects and mycoherbicide with soil-borne weed pathogen.

\section{Acknowledgements}

The authors are grateful to the Ministry of Higher Education Malaysia for provision of an FRGS research grant (FRGS/1/2014/ STWN03/UMK/01/1) and to the Faculty of Agro-Based Industry, Universiti Malaysia Kelantan, Jeli Campus for permission to carry out this research on their premise.

Authors' Contributions: All the authors collaborated in this work. S. M. R. Karim designed the study, Maszura Che Mat carried out the field works under the supervision of S. M. R. Karim, and Norhafizah Md Zain. Maszura Che Mat made the first draft, and S. M. R. Karim contributed to editing and formatting. The final draft read and approved by all the authors. 
Conflicts of Interest: The authors declare that there is no conflict of interest.

\section{References}

1. Adesina, G.O.; Akinyemiju, O.A.; Ola, O. Assessment of frequency, density and abundance of weed species in different cropping systems. J. Nat. Sci. Res. 2012, 2 (9), 107-119.

2. Anonymous. 2003. Parthenium Biological Control Agents. Department of Natural Resources and Mines, Queensland. Retrieved. December 9, 2014, Retrieved from http://www.weeds.org.au/WoNS/parthenium/docs/ Parthenium_Mgmnt-2.pdf.

3. Ayele, S.; Nigatu, L; Tana, T.; Adkins, S.W. Impact of parthenium weed (Parthenium hysterophorus L.) on the above-ground and soil seed bank communities of rangelands in Southeast Ethiopia. Int Res J Agric Sci Soil Sci 2013, 3(7), 262-274.

4. Begum, M.; Juraimi, A.S.; Syed Rastan, B.S.O.O. Amartalingam R; Man A.B. Seedbank and seedling emergence characteristics of weeds in ricefield soils of the muda granary area in north-west peninsular Malaysia. Biotropia 2006, 13(1), 11-21.

5. Buhler, D.D.; Kohler, K.A. Thompson R L. Weed seed bank dynamics during a five-year crop rotation. Weed Technol. 2009, 15(1), 170-176.

6. Department of Agriculture (DOA). Status pengesanan bancian Rumpai Miang Mexico di Semenanjung Malaysia sehingga 10 Feb 2015. Jemputan Mesyuarat Jawatankuasa Teknikal Program Kawalan, Pembendungan dan Penghapusan Rumpai Miang Mexico (Parthenium hysterophorus) Bil. 1. Plant Biosecurity Division:1-8. 2015.

7. Devi, Y.N.; Dutta, B.K.; Sagolshemcha, R; Singh, N.I. Allelopathic effect of Parthenium hysterophorus L. on growth and productivity of Zea mays L. and its phytochemical screening. Int. J. Curr. Microbiol. App. Sci. 2014, 3(7), 837-846.

8. Espinar, J.L.; Thompson, K.; García, L.V. Timing of seed dispersal generates a bimodal seed bank depth distribution. American J. Bot. 2005, 92(10), 1759-1763.

9. Golafshan, M.G.; Yasari, E. Comparison of sampling methods for estimating seed bank and weed population densities during the growing season. J. Agr. Sci. 2012, 4(9), 1-9.

10. Gomaa, N.H. Soil seed bank in different habitats of the Eastern Desert of Egypt. Saudi J Biol Sci 2012, 19, 211-220.

11. Gulden, R.H.; Shirtliffe, S.J. Weed Seed Banks: biology and management. Prairie Soils and Crops Journal 2009, 2, 46-52.

12. Karim, S.M.R.; Norhafizah, M.Z.; Maszura, C.M. Incidence of Parthenium allergy on human health in Kedah, Malaysia. Int J Biol Pharm Allied Sci. 2017a, 6(2), 175-182.

13. Karim, S.M.R.; Norhafizah, M.Z.; Maszura, C.M.; Fatimah, K.; Alam, M.Z. Perception of local people about Parthenium Weed (Rumpai Miang Mexico) in Kedah, Malaysia. Int J. Biol. Allied Sci. 2016, 5(5), 1006-1015.

14. Karim, S.M.R. Ill impacts of parthenium weed on human health, livestock production and environment. Seminar at West Virginia University, USA, 04 October 2012. Faculty of Agro Based Industry, University Malaysia Kelantan, Jeli Campus, 17600 Jeli, Kelantan 2012, 3: 1-5.

15. Karim, S.M.R.; Nurzafirah, Z.; Norhafizah, M.Z. Weed Seed bank of parthenium weed (Parthenium hysterophorus L.) in Batang Kali, Selangor, Malaysia. Pertanika J. Trop. Agric. Sci. 2017b, 40(4), 565-576.

16. Kaur, M.; Aggarwal, N.K.; Kumar, V.; Dhiman, R. Effects and management of Parthenium hysterophorus: A Weed of Global Significance. Hindawi Publishing Corporation International, Scholarly Research Notice 2014, 1-12.

17. Landau, S.; Everitt, B.S. A handbook of statistical analyses using SPSS. Washington D. C: Chapman \& Hall/CRC Press LLC, 2004.

18. Masum, S.M.; Hasanuzzaman, M.; Ali, M.H. Threats of Parthenium hysterophorus on agroecosystems and its management: a review. Intl J. Agri. Crop Sci. 2013, 6 (11): 684-697.

19. Menalled, F. Weed seedbank dynamics \& integrated management of agricultural weeds, in Montana State University guide. Retrieved from: 
http://www.ipm.montana.edu/cropweeds/documents_cropweeds/extension/weed\%20seedban k\%20dynamics\%20MT200808AG.pdf. 2008.

20. Mesgaran, M.B.; Mashhadi, H.R.; Zand, E.; Alizadeh, H.M. Comparison of three methodologies for efficient seed extraction in studies of soil weed seedbanks. European Weed Research Society, Weed Res. 2007, 47, 472-478.

21. Navie, S.C.; McFadyen, R.E.; Panetta, F.D.; Adkins, S.W. The biology of Australian weeds, 27. Parthenium hysterophorus L. Plant Protec. Qrt. 1996,11(2): 76-88.

22. Nguyen, T.L.T.; Navie, S.C.; Adkins, S.W. The reproductive capacity of parthenium weed (Parthenium hysterophorus L.) under different climatic conditions. 17th Australasian Weeds Conference, 2010, 124-127.

23. Noroozi S, Alizadeh M H, and Mashhadi R H. 2012. Factors affecting post dispersal of weed seed predation in barely fields. International Scholarly Research Network ISRN Agronomy 2012: 1-6.

24. Northern Territory Government. Parthenium Weed Parthenium Hysterophorus. Weed Management Act, Weed of National Significance (WoNS) 2013, 9: 1-3.

25. Parthasarathi, T.; Suganya, V.; Sivakumar, R. Allelopathic effect of aqueous leaf extract of Parthenium hysterophorus L. on seed germination and seedling growth in Greengram, Blackgram and Groundnut. Madras Agric. J. 2012, 99 (7-9), 514-517.

26. Patil, V.S. Rhizospheric Bacteria with the potential for biological control of Parthenium hysterophorus. J. Chem. Bio. Phy. Sci. Sec. B., 2013, 3(4), 2679-2686.

27. Price, J.N.; Wright, B.R.; Gross, C.L.; Whalley, W.R.D.B.. Comparison of seedling emergence and seed extraction techniques for estimating the composition of soil seed bank. Methods Ecol. Evol., 2010, 1: 151-157.

28. Sukumaran, T., Dangerous weed mushrooming. The Star: 4, December 9, 2014.

29. Worku, M. Prevalence and distribution survey of an Invasive Alien Weed (Parthenium hysterophorus L.) in Sheka Zone, Southwestern Ethiopia. Afr. J. Agric. Res. 2010, 5(9, 922-927.

30. Yang, D.; Li, W. Soil seed bank and aboveground vegetation along a successional gradient on the shores of an oxbow. Aquat. Bot. J. 2013, 110, 67-77. 